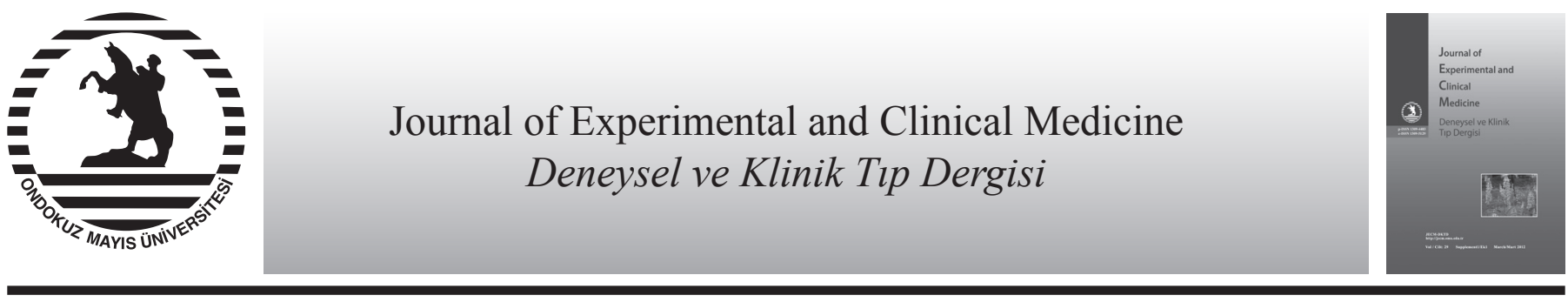

Derleme / Review

doi: $10.5835 /$ jecm.omu.29.s1.009

\title{
Tip 2 diabetes mellitusta insülin tedavisi
}

\author{
Insulin treatment in type 2 diabetes mellitus
}

\section{Hulusi Atmaca*}

Ondokuz Mayıs Üniversitesi, Tıp Fakültesi, Endokrinoloji ve Metabolizma Hastalıkları Bilim Dalı, Samsun, Türkiye

\begin{tabular}{|c|c|}
\hline MAKALE BİLGÍLERİ & ÖZET \\
\hline Makale geçmişi & tip 2 diyabetteki hiperglisemi tedavisinde mevcut tedaviler içerisinde en etkili \\
\hline Geliş & olanıdır. Uygun şekilde kullanıldığında, artmış HbA1C'yi arzulanan hedefe düşürebilir. \\
\hline Kabul & Tüm tip 1 diyabetiklere insulin tedavisi gerekli iken, tip 2 diyabetiklerde insulin teda- \\
\hline *Yazışma Adresi: & visinin nasıl olacağı veya ne zaman başlanacağı konusu o kadar açık değildir. Belirgin \\
\hline Hulusi Atmaca & kilo kaybı, ciddi hiperglisemi veya ketosis durumlarında insulin hemen başlanmalıdır. \\
\hline Ondokuz Mayıs Üniversitesi Tıp Fakültesi & Bu durumların dışında, insulin dışındaki tedavilerle veya bir veya daha fazla non-insülin \\
\hline Endokrinoloji ve Metabolizma Hastalıkları & ajanlarla glisemik hedeflere ulaşllamıyorsa insülin tedavisi eklenmelidir. Glukoz kontrolü \\
\hline Bilim Dalı \Samsun, Türkiye & nsulin tedavisi gözden \\
\hline E-posta:hatmaca@yahoo.com & J. Exp. Clin. Med., 2012;29:S44-S48 \\
\hline
\end{tabular}

Anahtar Kelimeler:

Tip 2 Diyabet

İnsan insülinleri

Analog insülinler

Bazal insülin

Bolus insülin

Bifazik insülin

Keywords:
Type 2 Diabetes
Human insulins
Analoque insulins
Basal insulin
Bolus insulin
Biphasic insulin

\begin{abstract}
Insulin is the most effective available medication for treating hyperglycemia in type 2 diabetes. If appropriately used, it can decrease any level of elevated $\mathrm{HbA1C}$ to, or close to, the desired goal. Whereas insulin therapy is required in all patients with type 1 diabetes, the decision of how and when to start insulin in type 2 diabetes is not as straightforward. Insulin usually should be started immediately in patients with marked weight loss, severe hyperglycemia, or ketosis. In the absence of these features, insulin should be added when glycemic goals are not met with one or more non-insulin agents, or when glycemic goals are unlikely to be achieved with non-insulin therapy. After the glucose is controlled and symptoms are relieved, it may be possible to withdraw the insulin or to be continued. Here, insulin therapy in patients with type 2 diabetes will be briefly reviewed. J. Exp. Clin. Med., 2012; 29:S44-S48
\end{abstract}

İnsülinin 1920'li yılların başlarında izole edilerek klinik kullanıma sunulması, diabetes mellitus (DM) tedavisinde devrim olmuştur. Günümüzde tüm tip $1 \mathrm{DM}$ 'li hastalarda ve tip 2 DM'li hastaların çoğunda insülin tedavisi gerekmektedir (Skyeler, 2004). Komplikasyonların azaltılmasında glisemik kontrolün önemi tip 1 diyabette kanıtlanmıştır (DCCT Research Group, 1993; Nathan ve ark., 2005). Aynı şekilde, UKPDS (United Kingdom Prospective Diabetes Study) çalışmasında da tip 2 diyabette sık1 glisemik kontrolle mikrovasküler komplikasyonlarda benzer azalma sağlandığ 1 , uzun vadede de makrovasküler komplikasyonlarda azalma olduğu ortaya konmuştur (UKPDS Group, 1998). UKPDS sonuçları göz önüne alındığında, tip 2 diyabette normogliseminin sağlanması hedef olmalıdır.
Diyabet tedavisinde kullanılan insülin preparatları

İnsülin uzun yıllar boyunca antijenik özellikler içeren ve alerjik yan etkisi olabilen sığır ve domuz pankreasından elde edilmiştir. Günümüzde insülinler rekombinant DNA teknolojisi ile üretilmektedir. Orijinal insan insülini ile aynı aminoasit zincirine sahip olduklarından "insan insülini”" olarak adlandırılmaktadırlar (Skyeler, 2004). Bunlar kısa etkili (regüler insülin) ve orta etkili (NPH: nötral protamin Hagedron) insülinlerdir. Aminoasit zincirinde yapılan değişikliklerle değişik farmakolojik özelliklere sahip insülinler üretilmiştir. Etki süreleri ve etkilerinin başlama süresi insan insülinlerine göre farklılık gösteren bu insülinlere "analog insülinler" denir. Hızlı etkili insülin analogları lispro, aspart ve glulisindir. Uzun etkili insülin analogları ise glargin ve detemirdir (Skyeler, 2004; İmamoğlu ve Ersoy, 2009; McCulloch ce 
Nathan, 2010). Ayrıca kısa veya hızlı etkili insülinlerin orta etkili insülinlerle oluşturulan hazır kombinasyonları (hazır karışım insülinler) da mevcuttur. Bunlar kısa etkili regüler insan insülini ve NPH karışımı, hızlı etkili lispro ve orta etkili nötral protamin lispro (NPL) karışımı ve hızlı etkili aspart ve orta etkili nötral protamin aspart (NPA) karışımıdır (İmamoğlu ve Ersoy, 2009). Karışım insülinler hasta tarafindan da hazırlanabilir. Ancak glargin ve detemir insülinleri hızlı etkili insülinlerle aynı şırıngada karıştırılamaz (McCulloch ve Nathan, 2010). Tablo 1'de ülkemizde mevcut olan insülinler ve özellikleri yer almaktadır.

\section{İnsan insülinleri ile analog insülinlerin karşılaştırıl- ması}

İnsan insülinleri pik ve etki süreleri, bazal insülinemi ve öğün sonrası hiperinsülinemisi açısından fizyolojik insülin salınımını taklit etmekten uzaktırlar. Bu nedenle ana$\log$ insülinler geliştirilmiştir. Hızlı etkili insülinlerin (lispro, aspart, glulisin) etkisi hemen ve hızlı başlar ve bu nedenle öğün öncesi yapıldıklarında öğün sonrası glikoz yükselişini önlemeye yeterli olabilirler. Glargin ve detemir insülin yapıldığında kanda pik etkiye yol açmadan daha uzun etki süreleri ile bazal insülinemi sağlarlar. Böylece hızlı etkili insülinlerin kısa etkili olarak bilinen regüler insüline göre etkileri daha erken başlar ve daha erken biter. Bu özellik geç postprandial dönemde hipoglisemi riskinin azalmasına yol açar. Uzun etkili analogların pik etkisinin olmaması bazal insülin olarak NPH'ya tercih edilmelerini sağlar. Çünkü pik etki artmış hipoglisemi riski ile beraberdir. Glargin ile detemir mukayese edildiğinde detemirin etki süresi glargine göre daha kısadır (nadiren 24 saate kadar uzayan) ve NPH kadar olmasa da pik etkisi vardır (McCulloch ve ark., 2011).

\section{Tip 2 diyabette insülin kullanma gerekçesi}

Sağlıklı bir bireyde insülin pulsatil olarak salgılanır. Pulslar bazal ve öğünlere cevap olarak iki şekilde cereyan eder. Bazal insülin salınımı günlük insülin üretiminin yaklaşık \%50'sini oluşturur. Geri kalan insülini prandial (öğünlerle stimüle olan) insülin oluşturur (McCulloch ve Nathan, 2010). Tip 2 diyabette her ne kadar insülin direnci önemli patojenik bir öge ise de insülin sekresyon defekti ilave olmadıkça kişide aşikar diyabet gelişmez. Yani tip 1 diyabet kadar olmasa da pankreas beta hücre defekti gelişir. Zamanla beta hücre fonksiyon bozukluğu progressif olarak ilerler ve tip 1 diyabete benzer şekilde insülin eksikliği ana defekti oluşturur. tip 1 diyabetten farklı olarak bu progresyon çok tedricidir ve yıllar içinde gerçekleşir.

Özetle; tip 2 diyabet hastalarında insülinin hem salgılanması hem de etkisi bozulmuştur. İnsülin salgılanmasındaki bozukluklar en az üç şekilde kendini gösterir:

1. Glukoza körelmiş ya da kaybolmuş ilk faz insülin yanıt1; bu durumda insülin salgılaması gecikmiştir ve öğünle birlikte oluşan glikoz artışlarını zamanında düzeltemez.

2. Glukoza insülin yanıtında duyarlılığın azalmış olması; bu durumda hiperglisemi uygun bir insülin yanıtı oluşturamaz.

3. Toplam insülin salgılama kapasitesinin azalmış olması; daha uzun süreli ve bu nedenle daha ciddi tip 2 diyabette ilerleyici niteliktedir.

İnsülin salgılama cevabındaki bu bozukluk statik değil, dinamiktir; öyle ki kronik hipergliseminin kendisi insülin salgılanmasındaki bozulmayı ağırlaştırabilir ve bu durum "glukoz toksisitesi" olarak bilinir. Bu nedenle, tip 2 diyabette glisemik kontrolün bu şekilde bozulmasıyla birlikte insülin salgılama yanıtı da bozulur. Ancak hipergliseminin düzeltilmesiyle pankreas beta hücresinin glukoza yanıtı bir miktar düzelir. Yani glukoz toksisitesinin geri dönüşümlü olması glukoz kontrolünün sürdürülmesini kolaylaştırır (Skyeler, 2004). Tip 2 diyabetteki diğer önemli bozukluk insülin direncidir. $\mathrm{Bu}$ da hastalarda kullanılması gereken toplam insülin dozunun artmasına neden olur. İnsülin salgılanmasındaki bozukluk gibi, insülin etkisindeki bu bozukluk da statik olmayıp dinamiktir. Kronik hiperglisemi insülin etkisindeki bozuklukları ağırlaştırabilir; bu da glukoz toksisitesinin diğer bir belirtisidir. Hiperglisemi düzeltildiğinde insülin direnci de bir miktar düzelir (Skyeler, 2004).

Tip 2 diyabetin patogenezi göz önüne alındığında, tedavinin değişmeyen ögeleri, sağlıklı beslenme, egzersiz ve kilo kaybı veya ideal kilonun sürdürülmesidir. Kontrendikasyon yoksa metformin ilk başlanması gereken ilaçtır. Yaşam tarzı değişikliği ile birlikte metformin etkisiz kalmaya başladığında ikinci bir oral ajan veya insülin eklenir. Hangi seçeneğin daha iyi olduğu konusunda bir fikir birliği olmamasına rağmen HbA1C'nin >\%8,5 olduğu durumlarda tercih insülinden yana olmalıdır. Bu aşamada genellikle günde tek doz bazal insülin kafi gelirken, zamanla günde iki doz bazal insülin veya karışım insülin gerekli hale gelebilir. Bu şemanın yetersiz kaldığ 1 durumlarda ise tip 1 diyabetteki gibi yoğun insülin tedavisi gündeme gelebilir. Yoğun insülin tedavisi, kompleks rejimlerin uygulandığ 1 , günde bir veya iki kere orta etkili insülinin (NPH) veya uzun etkili insülinin (detemir, glargin) bazal olarak verildiği; buna ilaveten öğün sonrası glikoz artışlarını karşılamak amacıyla günde üç veya daha fazla sayıda kısa (regüler) veya hızlı etkili (lispro, aspart, glulisin) insülinlerin verildiği şemalardır. Başta bu rejimler Tip 1 DM için kullanılmaktayken günümüzde uygun tip 2 DM'li hastalarda da kullanılmaktadır (McCulloch ve Nathan, 2010).

Farklı insülinlerin kullanımı ile iki türlü etki hedeflenir. Orta etkili veya uzun etkili insülinler hepatik glukoz üretimini baskılayarak açlık kan şekerini kontrol etmeye çalışırlar. Öğün öncesi bolus dozlarının uygulandığı kısa etkili veya hızlı etkili insülinler ise öğün sonrası glukoz yükselişini kontrol ederler. Karışım insülinlerle hem bazal hem öğün sonrası insülin ihtiyacı karşılanmaya çalışılır. Bifazik insülinler olarak da bilinirler. Bazen pik etkileri değişkenlik gösterebilir. $\mathrm{Bu}$ da glisemik kontrolü güçleştirebilir (McCulloch ve ark., 2011).

\section{Tip 2 diyabette insülin tedavi şemaları}

Tip 2 diyabet hastalarında önerilen kan glukozu hedefleri Tablo 2'de verilmiştir. Tedavi ile ilgili karar vermede hastaların diyabetin derecesine göre dört gruba ayrılması mümkündür (Skyeler, 2004).

Hafif tip 2 diyabet: Açlık kan şekeri $<126 \mathrm{mg} / \mathrm{dl}$ olan kişilerdir. Nadiren insülin kullanılır (Skyeler, 2004). Böyle hastaların yaşam tarzı ile ilgili önerilere dikkat etmeleri koşulu ile oral anti diyabetik tedavi (metformin) ile genellikle sorun yaşamazlar.

Orta derecede tip 2 diyabet: Açlık kan şekeri 126-200 $\mathrm{mg} / \mathrm{dl}$ arasında olanlardır (Skyeler, 2004). Oral tedavi ile glisemik kontrol sağlanamayan hastalarda, oral tedaviye bazal insülin (NPH, detemir, glargin) eklenebilir (McCulloch 
ve Nathan, 2010). Birlikte kullanılan metformin total insülin ihtiyacında azalma sağlar (Henry, 1993). Birçok çalışma insülin kombinasyonu ile gliseminin düzeldiğini ortaya koymuştur (Riddle ve ark., 2003; Hermansen ve ark., 2006; PhilisTsimikas ve ark., 2006; Yki-Järvinen ve ark., 2006). Bu kişilerde endojen insülin öğün sonrası kan şekeri yükselmelerini kontrol edebileceğinden bazal insülin genellikle yeterli olur. Bazal insülin olarak NPH insülin gece tek doz olarak uzun zamandır kullanılmaktadır. Daha uzun etkili olan insülin analoglarından detemir (gece tek doz veya günde 2 kere) ve glargin (günde tek doz) orta etkili NPH (günde tek doz veya 2 kere) ile karşılaştırıldığında HbAlC'yi azaltmada benzer bulunmalarına rağmen, uzun etkili analoglarla hipogliseminin daha az gözlendiği ortaya çıkmıştır (Haak ve ark., 2005; Yki-Järvinen ve ark., 2006). Fakat bu ajanlar NPH insüline göre daha pahalıdır. Uzun etkisi ile ve pik etkisinin olmaması ile glargin insülin yoğun insülin rejimlerinde bazal insülin olarak da tercih edilmesine neden olur. Detemirin de kanda belirgin pik etkisinin olmamasına karşın etki süresi glargine göre daha kısadır. Oral antidiyabetiklere glargin veya detemirin kombine edildiği bir çalışmada HbA1C'yi düşürmede benzer bulunmalarına rağmen, detemir kullanan hastaların $\% 55$ 'inde günde 2 kere insülin gereksinimi olmuş fakat glargin için günde tek doz yeterli oluştur (Rosenstock ve ark., 2008).

\section{Tablo 1. Ülkemizde kullanılan insülinler ve özellikleri}

\begin{tabular}{|c|c|c|c|c|}
\hline İnsülin çeşitleri & $\begin{array}{c}\text { Etkinin } \\
\text { başlama } \\
\text { süresi }\end{array}$ & Pik etki & $\begin{array}{c}\text { Etki } \\
\text { süresi* }\end{array}$ & Görünüm \\
\hline $\begin{array}{l}\text { Hızlı etkili analog } \\
\text { Lispro, Aspart, } \\
\text { Glulisin }\end{array}$ & 5-15 dak & $\begin{array}{l}45-75 \\
\text { dak. }\end{array}$ & 2-4 saat & Berrak \\
\hline $\begin{array}{l}\text { Kısa etkili insülin } \\
\text { Regüler insülin }\end{array}$ & $\sim 30$ dak & 2-4 saat & 5-8 saat & Berrak \\
\hline $\begin{array}{l}\text { Orta etkili insülin } \\
\mathrm{NPH}\end{array}$ & $\sim 2$ saat & 4-12 saat & $\begin{array}{c}18-28 \\
\text { saat }\end{array}$ & Bulanık \\
\hline $\begin{array}{l}\text { Uzun etkili insülin } \\
\text { Glargin }\end{array}$ & $\sim 2$ saat & Pik yok & $\begin{array}{c}20>24 \\
\text { saat }\end{array}$ & Berrak \\
\hline Detemir & $\sim 2$ saat & 3-9 saat & $\begin{array}{l}6-24 \\
\text { saat }^{*}\end{array}$ & Berrak \\
\hline $\begin{array}{l}\text { Karışım insan } \\
\text { insülinleri } \\
\mathrm{NPH} \% 70+\text { Regüler } \\
\% 30\end{array}$ & 30 dak & $\begin{array}{c}1,5-12 \\
\text { saat }\end{array}$ & 24 saat & Bulanık \\
\hline $\begin{array}{l}\text { Karışım insülin } \\
\text { analogları } \\
\text { Lispro protamin } \\
\% 75+\text { Lispro } \% 25\end{array}$ & $15-30$ dak & 2 saat & 22 saat & Bulanık \\
\hline $\begin{array}{l}\text { Lispro protamin } \\
\% 50+\text { Lispro } \% 50\end{array}$ & $15-30$ dak & 2 saat & 22 saat & Bulanık \\
\hline $\begin{array}{l}\text { Aspart protamin } \\
\% 70+\text { aspart } \% 30\end{array}$ & $10-20$ dak & 1-4 saat & 24 saat & Bulanık \\
\hline
\end{tabular}

Tablo 2. Tip 2 diyabet hastalarında hedef plazma glukoz düzeyleri

\begin{tabular}{lcl} 
& $\mathbf{m g} / \mathbf{d l}$ & $\mathbf{m m o l} / \mathbf{l}$ \\
\hline Açlık & $70-100$ & $3,9-5,6$ \\
Öğün sonrası & $100-180$ & $5,6-10,0$ \\
Yatmadan önce & $100-140$ & $5,6-7,8$ \\
\hline
\end{tabular}

Sonuç olarak insülin detemir ve glargin, NPH insüline göre semptomatik ve nokturnal hipoglisemi açısından daha avantajlıyken maliyet açısından daha pahalıdırlar. Tip 2 diyabet hastalarında oral antidiyabetiklere ilaveten NPH insülin veya detemir (gece yatmadan önce) veya glargin (sabah veya gece yatmadan önce) uygulanabilir. Eğer gece NPH alan hastada nokturnal hipoglisemi gelişirse gece NPH dozu azaltılır veya glargin insülin ile değiştirilir. NPH kullanan hastanın sabah açlık kan şekeri yüksek çıkarsa (somogy fenomeni değilse) NPH dozu artırılır veya daha geç saate kaydırılır (McCulloch ve ark., 2010).

Gereksinim duyulan bazal insülin dozu 0,3-0,4 Ü/kg/gün kadardır. Ancak $10 \mathrm{U}$ şeklinde de başlanır, üç günlük ortalama sabah açlık kan şekeri $>130 \mathrm{mg} / \mathrm{dl}$ ise, üç günde bir insülin dozu 2-4 Ü olarak artırılır ve hedef açlık glisemisi elde edilir (Nathan ve ark., 2006). Eğer açlık kan şekeri çok yüksek ise $(>250 \mathrm{mg} / \mathrm{dl})$ veya ciddi insülin direnci varsa başlangıç insülin dozu daha yüksek ve titrasyon daha agresif yapılabilir (Skyeler, 2004).

Ağır tip 2 diyabet: Açlık kan şekeri $>200 \mathrm{mg} / \mathrm{dl}$ olan kişilerdir. Bu gruptaki hastaların çoğunda yoğun insülin tedavisi gerekli olur. Başlangıçta hakim olan insülin direncini ve glukoz toksisitesini kırmak için $0,5-1,2$ Ü/ $/ \mathrm{kg} /$ gün insülin gerekebilir. Sonraki dönemlerde daha düşük dozlarla, günde iki doz karışım insülin, bazal insülin ile ya da sadece oral hipoglisemik ilaçlarla kontrol sürdürülebilir (Skyeler, 2004). Bazı hastalarda günde 2 kere NPH veya detemir veya tek doz glargin yeterli olabilir (Taylor ve ark., 2000; Rosenstock ve ark., 2001; Rosenstock ve ark., 2008). Bifazik insülin olarak adlandırılan karışım insülinlerin sabah kahvaltıdan önce ve akşam yemeğinden önce yapıldığında teorik olarak günde 4 kere pik etkiye (sabah, öğle, akşam ve gece pikleri) neden olurlar. Bu sayede hem bazal insülin hem de öğünler sonrası insülin gereksinimi karşılanmış olur (McCulloch ve Nathan, 2010). Bu protokolün başarısız kaldığı bazı hastalarda günde 3 kere karışım insülin uygun seçenek olabilir (Clements ve ark., 2008). HbA1C'yi düşürmede hızlı etkili karışım insülinler (aspart/protamin aspart ve lispro/protamin lispro) ile insan insülin karışımı (regüler+NPH) benzerdir. Ancak hızlı etkili karışımlar öğün sonrası glukozu azaltmada daha etkili, açlık glukozu azaltmada daha az etkili bulunmuştur (Qayyum ve ark., 2008). Diğer yandan hızlı etkili karışım insülinlerin hızl1 etkili analoglar gibi öğünden hemen önce uygulanabilme avantajları vardır.

Çok ağır tip 2 diyabet: Açlık kan şekeri >250-300 mg/dl olan kişilerdir. Bu hastalarda ögünlere endojen insülin cevabı da yetersiz kalır. İnsülin eksikliği belirgin olduğundan tip 1 diyabet gibi tedavi edilirler (Skyeler, 2004).

Çoğu tip 2 diyabet hastasında oral tedaviye bazal insülin eklendiğinde glisemik kontrol açısından yeterli olabilir. Fakat ilerleyen dönemlerde pankreas beta hücre kaybına paralel olarak bu kombinasyon yeterli olmamaktadır. Bazı hastalarda öğünler öncesi kısa veya hızlı etkili insülin ilavesi gerekli olabilir (McCulloch ve Nathan, 2010).

Randomize-kontrollü çalışmaların analiz edildiği bir meta analizde, tip 2 diyabetli hastalarda öğün öncesi bolus olarak kullanıldıklarında, hızlı ve kısa etkili insülinler karşılaştırılmıştır. HbAlc' ye etkileri ve hipoglisemi sıklığı bakımından fark görülmemiş olmasına rağmen hızlı etkili insülinlerin yemeklerden hemen önce (regüler insülin yemekten 20-30 dakika önce yapılmalı) yapılabilme kolaylığının yaşam 
kalitesi açısından önemli olduğu vurgulanmıştır (Plank ve ark., 2005). Öğün öncesi bolus insülin eklenecekse 4-6 U ile başlanır, doz 3 günde bir hedef ögün sonrası glikoz düzeyini yakalayana kadar 2-3 U artırılır. Ya da tip 1 diyabette daha yaygın kullanıldığı gibi daha kompleks bir yöntem olan karbonhidrat sayımına göre insülin dozu hesaplanarak verilir (McCulloch ve Nathan, 2010).

Tip 1 diyabettekinden farklı olarak, tip 2 diyabette bolus insülin uygulaması farklılıklar gösterir. Örneğin tip 1 diyabette bazal insülin ile birlikte ögünlerle beraber uygulanmak üzere günde üç kere hızlı veya kısa etkili insülin uygulaması yapılır. tip 2 diyabette bazal insüline ilaveten hangi öğün sonrası kan şekeri hedefin üzerinde ise o ögünde bolus insülin yapılabilir. Bu şekilde bolus insülin bir ya da birkaç öğünde yapılabilir (İmamoğlu ve Ersoy, 2009). Yoğun insülin tedavisi ile daha iyi glisemik kontrol sağlanmasına rağmen, bu konu ile ilgili en önemli sorun kilo alımıdır. Ortalama kilo alımı 6-9 kg olabilmektedir (Henry ve ark., 1993).

Tip 2 diyabet hastalarında glisemik kontrol sağlandığında fizyopatolojik bozukluklar düzelir. Bu da kontrolü kolaylaştırır ve başlangıçta insülinle tedavi edilen hastaların oral hipoglisemik ajanlar ile, hatta sadece diyet ve egzersiz ile tedaviyi sürdürmelerine imkan verebilir (Skyeler, 2004). Çoğu tip 2 diyabet hastası diyet ve egzersiz programına uyarsa, insülinle kontrolde tutulabilir. Diyet ve egzersiz programına uyma insülinin etkisini artırır. Aksi halde hiperglisemi geliştikçe artırılacak insülin dozu ile bir kısır döngüye girilmiş olur. $\mathrm{Bu}$ nedenle her vizitte hastalar yaşam biçimi açısından kontrol edilmeli ve gerekli önlemler açısından motive edilmelidirler.

Tip 2 diyabet tedavisinde insülin dozunun hesaplanması

Tip 1 diyabetik hastaların ortalama günlük insülin ihtiyac1 0,5-1,0 U/kg, tip 2 diyabet hastalarında ise 0,2-2 U/kg'dır. İnsülin dozları belirlenirken hastanın beslenmesi, aktivite durumu, entelektüel düzeyi ve yandaş hastalıkları dikkate alınmalı ve tedavi kişiselleştirilmelidir. Günde tek doz bazal insülin planlanıyorsa hesaplanan toplam doz ile veya $10 \mathrm{U} /$ gün olarak başlanır ve açlık kan şekerine göre hedef glisemiye ulaşana kadar doz yukarda ayrıntıları belirtilen şekilde artırılır. Açlık kan şekeri hedefine ulaştıktan sonra ögüun sonrası (yemekten 2 saat sonra) kan şekeri kontrol edilir. Hedef postprandial kan şekerine ulaşılamamışsa karışım insüline geçilebilir veya kan şekerinin yüksek kaydedildiği öğün veya öğünlerin öncesine bolus insülin ilave edilir. Günde 2 doz bazal insülin verilecekse total dozun yarısı sabah diğer yarısı akşam verilebilir. Günde iki kere regüler/NPH karışım insülin verilecekse hesaplanan dozun 2/3'ü sabah, 1/3'ü akşam verilebilir. Hızlı etkili karışım verilecekse aynı şekilde verilebilir veya hesaplanan dozun yarısı sabah, yarısı akşam olacak şekilde başlanır. Yoğun insülin tedavisinde hesaplanan toplam dozun yarısı bazal insülin yarısı da bolus insülin olarak eşit miktarda öğünlere bölünür. Eğer bazal insülin olarak $\mathrm{NPH}$ verilecekse hesaplanan toplam dozun 1/4'ü gece NPH olarak, her öğün öncesi de $1 / 4$ bolus insülin verilir. Örneğin verilecek toplam doz $48 \mathrm{U}$ ise; $24 \mathrm{U}$ glargin veya detemir, sabah, öğle ve akşam yemeklerinden önce 8'er U hızlı veya kısa etkili insülin başlanır. Bazal insülin NPH olarak verilecekse 12 U gece, her öğün öncesi 12 U kısa veya hızlı etkili insülin olarak başlanır. İnsan insülinleri $(\mathrm{NPH}$, regüler veya karışımları) öğünlerden 20-30 dakika önce, hızlı analog insülinler veya karışımları öğünlerden hemen önce ve uzun etkili analoglar ise öğünle ilişkisiz olarak alınabilirler (Skyeler, 2004; İmamoğlu ve Ersoy, 2009; TEMD, 2010).

\section{Başlangıç tedavisi olarak veya geçici süreli olarak in- sülin tedavisi}

Nadiren başvurulan bir yöntem olmasına rağmen tip 2 diyabet tanısı konduğunda 2-4 haftalık yoğun insülin tedavisi ile başlamanın uzun vadede iyi olabileceği yönünde çalışmalar vardır. Yoğun insülin tedavisi sayesinde endojen insülin sekresyonunun ve insülin sensitivitesinin düzeldiği gözlenmiştir (Garvey ve ark., 1985; Ilkova ve ark., 1997; Ryan ve ark., 2004; Li ve ark., 2004). İnsülin tedavisi ile glukoz toksisitesi önlenerek beta hücre fonksiyonu iyileşir ve bazı hastalarda insülinin kesilmesine rağmen tek başına diyet ve egzersiz ile uzun süre normoglisemi sağlanabilir (McCulloch ve Nathan, 2010).

Ayrıca tip 2 diyabet hastalarında başlangıçta glisemik kontrol elde etmek, glukoz toksisitesinin üstesinden gelmek ve dekompanse olan hastaların yeniden regülasyonunu sağlamak üzere geçici olarak insülin tedavisinin kullanılması daha yaygın bir yaklaşımdır. Mevcut oral tedaviye insülin (bazal veya karışım) eklenerek veya metformin ile birlikte yoğun insülin tedavisi başlamak, araya giren hastalık veya stres nedeniyle dekompanse olan hastalarda veya var olan glukoz toksisitesini tedavi etmek açısından çok etkili bir yaklaşımdır (Skyeler, 2004).

Tanı anında veya takip sırasında, HbA1C $>\% 10$, açlık kan şekeri $>250 \mathrm{mg} / \mathrm{dl}$, rastgele kan glikozu $>300 \mathrm{mg} / \mathrm{dl}$, ketonüri ve istem dışı kilo kaybı varsa insülin başlanmalıdır (McCulloch ve Nathan, 2010).

\section{Erişkin başlangıçıı tip 1 diyabet}

Bazı erişkin hastalar tanı anında tip 2 DM oldukları düşünüldükleri halde bu hastalar erişkin başlangıçlı tip $1 \mathrm{DM}$ olabilirler. Tip 1 DM'nin pik insidansı puberte dönemi olmasına rağmen vakaların yaklaşık \%25'inde tip 1 DM 35 yaşından sonra başlar (Leslie ve Elliott, 1994). Herhangi bir yaştaki bir hastada belirgin ve başka sebeplerle açıklanamayan kilo kaybı varsa (önceki kilosu ne olursa olsun), kısa süre içinde başlayan hiperglisemik semptomlar, ketonüri ve ilk prezentasyonun diyabetik ketoasidoz olması tip 1 diyabet tanısını destekler ve insülin başlanmasını gerektirir (McCulloch ve Nathan, 2010).

Bazı yetişkin başlangıçlı tip 1 diyabetli hastaların insülin gereksinimi yavaş gelişir ve tip 2 DM olarak tanı alırlar. Bu durum "latent autoimmune diabetes in adults" (LADA) olarak bilinir. LADA pankreatik otoantikorların (anti GAD gibi) gösterilmesi ile tip 2 DM'den ayırt edilebilir. Böyle hastalar oral anti diyabetiklere zayıf cevap verirler ve kısa zamanda insülin ihtiyacı gelişir (McCulloch, 2010).

\section{KAYNAKLAR}

Clements, M.R., Tits, J., Kinsley, B.T., Råstam, J., Friberg, H.H., Ligthelm, R.J., 2008. Improved glycaemic control of thrice-daily biphasic insulin aspart compared with twice-daily biphasic human insulin; a randomized, open-label trial in patients with type 1 or type 2 diabetes. 
Diabetes Obes. Metab. 10, 229-237.

DCCT (The Diabetes Control and Complications Trial Research Group), 1993. The effect of intensive treatment of diabetes on the development and progression of long- term complications in insulin-dependent diabetes mellitus. N. Engl. J. Med. 329, 977-986.

Garvey, W.T., Olefsky, J.M., Griffin, J., Hamman, R.F., Kolterman, O.G., 1985. The effect of insulin treatment on insulin secretion and insulin action in type II diabetes mellitus. Diabetes. 34, 222-234.

Haak, T., Tiengo, A., Draeger, E., Suntum, M., Waldhäusl, W., 2005. Lower within-subject variability of fasting blood glucose and reduced weight gain with insulin detemir compared to NPH insulin in patients with type 2 diabetes. Diabetes. Obes. Metab. 7, 56-64.

Henry, R.R., Gumbiner, B., Ditzler, T., Wallace, P., Lyon, R, Glauber, H.S., 1993. Intensive conventional insulin therapy for type II diabetes. Metabolic effects during a 6-mo outpatient trial. Diabetes Care 16, 21-31.

Hermansen, K., Davies, M., Derezinski, T., Martinez, R.G., Clauson, P., Home, P., 2006. A 26-week, randomized, parallel, treat-to-target trial comparing insulin detemir with NPH insulin as add-on therapy to oral glucose-lowering drugs in insulin-naive people with type 2 diabetes. Diabetes Care 29, 1269-1274.

Ilkova, H., Glaser, B., Tunçkale, A., Bagriaçik, N., Cerasi, E., 1997. Induction of long-term glycemic control in newly diagnosed type 2 diabetic patients by transient intensive insulin treatment. Diabetes Care 20,1353-1356.

İmamoğlu, Ş., Ersoy, C.Ö., 2009. Diabetes mellitus’ta insülin tedavisi. Diabetes Mellitus, 2. bask1, İmamoğlu, Ş., Ersoy, C.Ö, eds. Deomed, İstanbul, pp.178-188.

Leslie, R.D., Elliott, R.B., 1994. Early environmental events as a cause of IDDM. Evidence and implications. Diabetes 43, 843-850.

Li, Y., Xu, W., Liao, Z., Yao, B., Chen, X., Huang, Z., Hu, G., Weng, J., 2004. Induction of long-term glycemic control in newly diagnosed type 2 diabetic patients is associated with improvement of beta-cell function. Diabetes Care 27, 2597-2602.

McCulloch, D.K., Nathan, D.M., Ocak 2010, http://www.uptodate.com/contents/insulin-therapy-in-type-2-diabetes-mellitus.

McCulloch, D.K., Nathan, D.M., Mulder, J.E., Şubat 2011. General principles of insulin therapy in diabetes mellitus. http://www.uptodate.com/ contents/general-principles-of- insulin-therapy-in-diabetes-mellitus.

Nathan, D.M., Cleary, P.A., Backlund, J.Y., Genuth, S.M., Lachin, J.M., Orchard, T.J., Raskin, P., Zinman, B., 2005. Intensive diabetes treatment and cardiovascular disease in patients with type 1 diabetes. N. Engl. J. Med. 22, 2643-2653.

Nathan, D.M., Buse, J.B., Davidson, M.B., Heine, R.J., Holman, R.R., Sherwin, R., Zinman, B., 2006. Management of hyperglycemia in type 2 diabetes: A consensus algorithm for the initiation and adjustment of therapy: a consensus statement from the American Diabetes Association and the European Association for the Study of Diabetes. Diabetes Care 29, 1963-1972.

Philis-Tsimikas, A., Charpentier, G., Clauson, P., Ravn, G.M., Roberts, V.L., Thorsteinsson, B., 2006. Comparison of once-daily insulin detemir with NPH insulin added to a regimen of oral antidiabetic drugs in poorly controlled type 2 diabetes. Clin. Ther. 28, 1569-1581.

Plank, J., Siebenhofer, A., Berghold, A., Jeitler, K., Horvath, K., Mrak, P., Pieber, T.R., 2005. Systematic review and meta-analysis of shortacting insulin analogues in patients with diabetes mellitus. Arch. Intern. Med. 165, 1337-1344.

Qayyum, R., Bolen, S., Maruthur, N., Feldman, L., Wilson, L.M., Marinopoulos, S.S., Ranasinghe, P., Amer, M., Bass, E.B., 2008. Systematic review: Comparative effectiveness and safety of premixed insulin analogues in type 2 diabetes. Ann. Intern. Med. 149, 549-559.

Riddle, M.C., Rosenstock, J., Gerich, J., 2003. Insulin Glargine 4002 Study Investigators. The treat-to-target trial: Randomized addition of glargine or human NPH insulin to oral therapy of type 2 diabetic patients. Diabetes Care 26, 3080-3086.

Rosenstock, J., Davies, M., Home, P.D., Larsen, J., Koenen, C., Schernthaner, G., 2008. A randomised, 52-week, treat-to-target trial comparing insulin detemir with insulin glargine when administered as add-on to glucose-lowering drugs in insulin-naive people with type 2 diabetes. Diabetologia 51,408-416.

Rosenstock, J., Schwartz, S.L., Clark, C.M., Jr Park, G.D., Donley, D.W., Edwards, M.B., 2001. Basal insulin therapy in type 2 diabetes: 28 -week comparison of insulin glargine (HOE 901) and NPH insulin. Diabetes Care 24, 631-636.

Ryan, E.A., Imes, S., Wallace, C., 2004. Short-term intensive insulin therapy in newly diagnosed type 2 diabetes. Diabetes Care 27, 10281032.

Skyeler, J.S., 2004. Insulin therapy. Therapy for diabetes mellitus and related disorders, 4th ed., Lebovitz, H.E., ed. American Diabetes Association, Inc., pp.211-227.

Taylor, R., Davies, R., Fox, C., Sampson, M., Weaver, J.U., Wood, L., 2000. Appropriate insulin regimes for type 2 diabetes: A multicenter randomized crossover study. Diabetes Care 23, 1612-1618.

TEMD (Türkiye Endokrinoloji ve Metabolizma Derneği), Diabetes Mellitus Çalışma Grubu, Diabetes Mellitus ve Komplikasyonlarının Tanı, Tedavi ve İzlem Kılavuzu, 2010.

UKPDS (UK Prospective Diabetes Study) Group,1998. Intensive blood-glucose control with sulphonylureas or insulin compared with conventional treatment and risk of complications in patients with type 2 diabetes (UKPDS 33). Lancet 352, 837-853.

Yki-Järvinen, H., Kauppinen-Mäkelin, R., Tiikkainen, M., Vähätalo, M., Virtamo, H, Nikkilä, K., Tulokas, T., Hulme, S., Hardy, K., McNulty, S., Hänninen, J., Levänen, H., Lahdenperä, S., Lehtonen, R., Ryysy, L., 2006. Insulin glargine or NPH combined with metformin in type 2 diabetes: The LANMET study. Diabetologia 49, 442-451. 